\title{
MANAJEMEN PEMBELAJARAN APEL (ANAK PELAKU PEMBELAJARAN) UNTUK MENINGKATKAN KREATIVITAS SISWA
}

\author{
Pandu Satyabrata $^{a)}$, Rita Retnowati ${ }^{\left.b^{*}\right)}$, Yossa Istiadi ${ }^{b)}$ \\ ${ }^{a)}$ SMP Kabupaten Bogor, Bogor, Indonesia

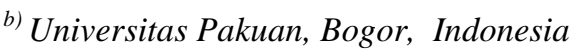 \\ *e-mail korespondensi: ritaretnowati@unpak.ac.id
}

riwayat artikel: diterima: 19 Maret 2020; direvisi: 28 Maret 2020; disetujui: 29 April 2020

\begin{abstract}
Abstrak. Pemerataan pendidikan utamanya di daerah tertinggal di Indonesia sampai saat ini masih menjadi masalah. Diperlukan pihak swasta berperan aktif untuk membantu upaya pemerintah. Di masa sekarang banyak sekolah ikut membantu upaya dalam pemerataan pendidikan, salah satunya adalah Sekolah Anak Indonesia, yang semua siswanya berasal dari Papua. Sekolah Anak Indonesia memiliki model pembelajaran yang dikembangkan secara internal yaitu APEL (Anak Pelaku Pembelajaran), dengan tujuan sebagai media membantu siswa untuk bisa mengejar ketertinggalan khususnya di bidang akademik serta membantu siswa untuk menguasai kecakapan Abad 21 yaitu kecakapan 4C (collaboration, critical thinking, communication and creativity), khusus pada kreatifitas, siswa dibantu untuk dapat menciptakan inovasi sebagai solusi di tengah masyarakat, hal ini dapat menjadi bekal siswa untuk percaya diri terjun di masyarakat. Penelitian ini bertujuan untuk mengkaji dan mendeskripsikan keunikan atau kekhasan proses dan tahapan dalam manajemen pembelajaran APEL di Sekolah Anak Indonesia, yang terletak di Sentul-Bogor, pada jenjang Sekolah Menengah Pertama. Manajemen pembelajaran APEL yang dikaji meliputi tahapan perencanaan, pengorganisasian, pengarahan dan pelaksanaan, serta pengendalian. Penelitian ini menggunakan metode kualitatif, dengan peneliti sebagai instrumen. Teknik pengambilan data yang digunakan dengan wawancara, observasi, dan studi dokumentasi. Berdasarkan data dan informasi yang ada, diperoleh hasil dan dapat disimpulkan bahwa proses perencanaan, pengorganisasian, pengarahan, dan pengendalian yang baik dan terstruktur menjadi faktor utama dalam pembelajaran APEL di Sekolah Menengah Pertama Sekolah Anak Indonesia. Untuk dapat mencetak anak yang kreatif maka dalam pembelajaran APEL diperlukan perencanaan yang detail dan ajeg, pengorganisasian yang sesuai dengan kebutuhan, pengarahan serta implementasi sesuai dengan program yang telah disusun dan direncanakan, serta pengendalian yang intensif secara berkala dengan instrumen yang disusun secara objektif sesuai dengan kondisi perkembangan pembelajaran siswa.
\end{abstract}

Kata Kunci: manajemen; model pembelajaran APEL; kreativitas

\section{MANAGEMENT OF STUDENTS LEARNING (CHILDREN LEARNERS) TO IMPROVE STUDENT CREATIVITY FROM PAPUA AT THE FIRST MIDDLE SCHOOL IN SENTUL INDONESIAN CHILDREN'S SCHOOL, BOGOR}

\begin{abstract}
Educational distribution, especially at under developed region in Indonesia, is still facing a problem. It is necessary that the private sector takes more active role to assist government efforts. Nowadays, many school institutions takes an effort to equalize education, such as Sekolah Anak Indonesia, where all of his students comes from Papua. Sekolah Anak Indonesia implements an internal developed learning model which is called APEL (Anak Pelaku Pembelajaran). The goal of the school is to help students to catch up their left behind, especially in the academic field and helping students to master 21st Century skills, namely 4C skills (collaboration, critical thinking, communication and creativity). On the area of creativity, students are helped to be able to create innovation as a solution in society, so students confidently go into society. This research is intended to study and describe the uniqueness or special characteristics of management process' and steps of learning model APEL of a Junior High School which located in Sentul-Bogor. The management of learning model APEL covered four stages of study, they are planning, organizing, directing and implementing, and controlling. This research was conducted through qualitative methods, where the researcher as its instrument. The retrieval data technique was conducted by interviewing, observation, and documentation studies. Based on the collected data and information, this thesis found out and concluded that good structural process of planning, organizing, directing, and controlling become the main supporting factor during using the APEL learning model in junior high school level in the Sekolah Anak Indonesia. In order to be able to produce creative children, it needs detail and consistency in planning, organization which based on the needs, direction and implementation that is in accordance with components of program which has been arranged and planned in advance, as well as regular intensive control using objective instruments that meet students' learning development.
\end{abstract}

Keywords: management; the APEL learning model; creativity

\section{PENDAHULUAN}

Sekolah merupakan hal yang penting untuk kehidupan manusia, karena dengan tidak adanya sekolah maka kualitas pendidikan masyarakat yang ada jadi terganggu. Tentu seiring perkembangan jaman banyak permasalahan di dunia pendidikan, 
utamanya menyangkut pemerataan dan kualitas pendidikan. Fenomena yang sering terdengar di masa kini adalah masih banyak daerah yang belum terjamah oleh pendidikan yang setara dengan di kota besar di Indonesia, yaitu di daerah 3T (Tertinggal, Terluar, Terdepan), misalnya di Papua. Di Indonesia sudah banyak yayasan pendidikan yang peduli dan berperan membantu dalam pemerataan kualitas. Salah satunya adalah Sekolah Anak Indonesia yang terletak di Sentul, Bogor. Sekolah Anak Indonesia menggunakan model pembelajaran hasil pengembangan sendiri yang mana sebagai media percepatan anak dalam menerima pelajaran, selain itu dinyatakan dapat menumbuhkan soft skill, salah satunya komunikasi serta merangsang anak untuk menjadi kreatif, model pembelajaran tersebut yaitu model pembelajaran APEL (Anak Pelaku Pembelajaran), model ini sebagian besar mengadopsi Student Centered Learning, yaitu pembelajaran fokus pada anak, selain itu dikombinasikan dengan beberapa model pembelajaran lainnya seperti, discovery learning, inkuiri, konstruktivisme, saintifik dan problem based learning. Pada pembelajaran APEL siswa diarahkan dan dibimbing untuk berpikir kreatif.

Tentu saja manajemen sekolah yang terkelola dengan baik sangat berperan dalam keberhasilan Sekolah Anak Indonesia menghasilkan siswa yang mampu mencapai kemampuan standar, menjadi pribadi kreatif dan sukses di berbagai bidang. Oleh karena itu, pada penelitian ini akan dikaji lebih mendalam mengenai bagaimana manajemen pembelajaran APEL (Anak Pelaku Pembelajaran) untuk meningkatkan kreativitas siswa dari Papua pada jenjang Sekolah Menengah Pertama di Sekolah Anak Indonesia Sentul, Bogor.. Sebuah organisasi dapat dikatakan berhasil jika dalam pelaksanaannya terdapat pengelolaan yang baik, karena pengelolaan ini berfungsi untuk membantu mencapai tujuan organisasi yang ditetapkan sejak awal. Konsep pengelolaan selanjutnya dikenal sebagai manajemen. Istilah pembelajaran berhubungan erat dengan pengertian belajar mengajar. Belajar dapat terjadi tanpa guru atau tanpa kegiatan mengajar dan pembelajaran formal lain. Sementara itu pembelajaran adalah suatu usaha yang sengaja melibatkan dan menggunakan pengetahuan profesional yang dimiliki guru untuk mencapai tujuan kurikulum (Muhlasin, 2019: 62-75). Manajemen pembelajaran dapat bermakna sebagai usaha ke arah pencapaian tujuan tujuan pembelajaran yang dilakukan melalui aktivitas - aktivitas orang lain atau membuat suatu kegiatan yang dikerjakan oleh orang lain berupa peningkatan minat, perhatian, kesenangan dan latar belakang siswa (orang yang belajar), dengan memperluas cakupan aktivitas (tidak terlalu dibatasi), serta mengarah kepada pengembangan gaya hidup di masa mendatang (Sulaeman dan Djaswidi, 2017:99-132).

Senada dengan hal tersebut Priyadi (2017:86-102) juga menyatakan bahwa manajemen pembelajaran merupakan proses mengelola yang meliputi kegiatan perencanaan, pengorganisasian, pengarahan dan pengevaluasian kegiatan yang berkaitan dengan proses membelajarkan siswa dengan mengikut-sertakan berbagai faktor di dalamnya guna mencapai tujuan. Berdasarkan beberapa pendapat diatas mengenai manajemen pembelajaran, maka dapat disintesiskan manajemen pembelajaran merupakan upaya mengelola proses belajar mengajar yang meliputi kegiatan perencanaan, pengorganisasian, pengendalian (pengarahan) dan pengevaluasian yang dilakukan kepala sekolah sebagai manajer sekolah dan guru sebagai manajer di kelas, secara efektif dan efisien dalam mencapai tujuan sekolah. Fungsi Dasar Manajemen: Perencanaan (Planning), Pengorganisasian (Organizing), Pengarahan (Actuating), dan Pengendalian (Controlling)

Pendekatan ini memberikan kebebasan kepada siswa untuk memiliki kesempatan menggali sendiri ilmu pengetahuannya sehingga akan didapat pengetahuan yang mendalam (deep learning) dan mampu meningkatkan kualitas siswa. Model pembelajaran ini menempatkan siswa yang aktif, mandiri, bertanggung jawab sepenuhnya atas pembelajarannya, serta mampu belajar di luar kelas. Pada pembelajaran student centered learning guru tidak hanya dituntut untuk mengajar saja di depan kelas melainkan juga berperan membantu peserta didik untuk memecahkan masalah saat mereka mengalami kesulitan dalam proses pembelajaran (Millah, 2015:255-278). Pendapat lain menyatakan SCL atau Student Centered Learning merupakan pendekatan dalam pembelajaran yang memfasilitasi pembelajar untuk terlibat dalam proses experiential learning. SCL tersebut merupakan metode yang dapat memfasilitasi pembelajar sehingga secara langsung ataupun tidak dapat terlibat dalam proses pembelajaran (Kurdi, 2009:108-113). Berdasarkan pendapat diatas mengenai student centered learning, maka dapat ditarik sintesis bahwa student centered learning adalah model pembelajaran yang berpusat pada siswa, artinya siswa diberi kebebasan untuk mencari dan menggali pengetahuan sendiri secara aktif, sehingga siswa bisa kreatif dan mengkontruksi pengetahuan itu sendiri, peran guru bukan lagi sebagai sumber pengetahuan utama, guru pada pembelajaran ini berfungsi sebagai fasilitator atau mitra pembelajaran yang membantu mengarahkan dalam proses pembelajaran dan membantu siswa dalam memecahkan masalah jika timbul permasalahan.

Penemuan (discovery) merupakan suatu model pembelajaran yang dikembangkan berdasarkan pandangan konstruktivisme. Discovery Learning adalah pembelajaran aktif dengan menanamkan sikap dalam penelitian. Siswa dapat mengembangkan diri sesuai dengan kemampuannya dalam menerapkan pembelajaran sehingga siswa menjadi mudah memahami materi dengan baik, tidak hanya terbatas pada teori, tetapi juga penerapannya dalam masyarakat. Belajar penemuan pada akhirnya dapat meningkatkan penalaran dan kemampuan untuk berpikir secara bebas dan melatih keterampilan kognitif siswa dengan cara menemukan dan memecahkan masalah yang ditemui dengan pengetahuan yang telah dimiliki dan menghasilkan pengetahuan yang benar - benar bermakna bagi dirinya (Mubarok dan Sulistyo, 2014:215-221). Salmi (2019:1-16) berpendapat bahwa model discovery learning adalah suatu proses pembelajaran yang penyampaian materinya disajikan secara tidak lengkap dan menuntut peserta didik terlibat secara aktif untuk menemukan sendiri suatu konsep ataupun prinsip yang belum diketahuinya. Dari pendapat diatas dapat disintesis bahwa discovery learning adalah pembelajaran yang pada prosesnya pengetahuan tidak diberikan secara menyeluruh, namun melibatkan dan mengarahkan siswa aktif dalam menemukan, mengorganisasi, menyelidiki dan mengembangkan pengetahuan itu sendiri melalui berbagai informasi atau data yang diperoleh 
dari pengamatan atau percobaan sehingga hasil yang diperoleh akan setia dan tahan lama dalam ingatan, tidak akan mudah dilupakan oleh siswa.

PBL adalah salah satu model aliran pembelajaran konstruktivis yang menuntut siswa melakukan pengamatan realitas yang terdapat dalam kehidupan sehari - hari. Menurut teori konstruktivisme, keterampilan berpikir dan memecahkan masalah dapat dikembangkan jika peserta didik melakukan sendiri, menemukan dan memindahkan kekomplekan pengetahuan yang ada. PBL merupakan pembelajaran berdasarkan teori kognitif yang didalamnya termasuk teori belajar konstruktivisme. PBL merupakan suatu pendekatan pembelajaran yang menggunakan masalah dunia nyata sebagai suatu konteks bagi peserta didik untuk belajar tentang cara berpikir kritis dan keterampilan pemecahan masalah, serta untuk memperoleh pengetahuan dan konsep yang esensial dari materi pelajaran (Nafiah, 2014:125-143). Pendapat lain menyatakan pembelajaran berbasis masalah atau Problem Based Learning adalah pembelajaran yang memiliki esensi berupa penyuguhan berbagai bermasalah yang autentik dan bermakna kepada peserta didik, yang dapat berfungsi sebagai sarana untuk melakukan investigasi dan penyelidikan. Jadi, peran guru dalam pembelajaran adalah memberikan berbagai masalah, pertanyaan, dan memberikan fasilitas terhadap penyelidikan peserta didik (Rerung 2017: 47-55). Sintesis dari beberapa pernyataan diatas bahwa model pembelajaran problem based learning adalah pembelajaran dengan menggunakan masalah nyata dengan tujuan untuk mengasah kemampuan berpikir kritis dan kreatif serta melatih siswa menyelesaikan masalah sehingga terbentuk solusi dari permasalahan tersebut sebagai pengetahuan dan konsep yang esensial dari pembelajaran

Pembelajaran berbasis inkuiri adalah sarana untuk mengembangkan keterampilan berpikir kritis siswa. Model pembelajaran inkuiri menurut Gulo (dalam Andiasari, 2015: 15-20) adalah suatu rangkaian kegiatan belajar yang melibatkan secara maksimal seluruh kemampuan siswa untuk mencari dan menyelidiki secara sistematis, kritis, logis dan analitis sehingga siswa dapat merumuskan sendiri penemuannya dengan penuh percaya diri. Berbeda dengan metode ceramah, pada model pembelajaran inkuiri siswa lebih dilibatkan pada proses pembelajarannya. Siswa akan lebih aktif dalam proses pembelajaran sehingga tingkat kejenuhan siswa dapat diminimalisir. Bukan hanya itu saja, dalam model pembelajaran inkuiri siswa tidak hanya menghafal materi yang disampaikan saja tapi juga melakukan pengamatan sehingga siswa dapat memahami secara mendalam materi yang dipelajari (Prasetyo, 2015:82-86).

Dari beberapa pendapat tersebut diatas, maka sintesisnya bahwa model pembelajaraan inkuiri adalah proses belajar yang menekankan bahwa pengetahuan bukanlah sejumlah fakta hasil dari mengingat namun melalui proses menemukan sendiri, memperoleh dan mendapatkan informasi dengan melakukan observasi atau eksperimen untuk mencari jawaban atau memecahkan masalah terhadap pertanyaan atau rumusan masalah melalui berfikir secara sistematis, kritis, dan analisis sehingga di harapkan dapat menumbuhkan sikap percaya diri. Pendekatan pembelajaran saintifik adalah proses pembelajaran yang dirancang agar peserta didik secara aktif mengonstruk konsep, hukum atau prinsip melalui tahapan - tahapan mengamati, menanya, menalar, mencoba, membentuk jejaring untuk semua mata pelajaran (Setiawan, 2017:34-46). Sufairoh (2016:116-125) berpendapat sama dengan menyatakan bahwa pembelajaran dengan pendekatan saintifik adalah proses pembelajaran yang dirancang sedemikian rupa agar peserta didik secara aktif mengkonstruk konsep, hukum atau prinsip melalui tahapan - tahapan mengamati (untuk mengidentifikasi atau menemukan masalah), merumuskan masalah, mengajukan atau merumuskan hipotesis, mengumpulkan data dengan berbagai teknik, menganalisis data, menarik kesimpulan dan mengomunikasikan konsep, hukum atau prinsip yang "ditemukan".

Pendekatan saintifik merupakan pendekatan yang berpusat kepada peserta didik agar peserta didik secara aktif mengkonstruksi konsep, hukum atau prinsip melalui tahapan - tahapan mengamati, merumuskan masalah, mengajukan atau merumuskan hipotesis, mengumpulkan data dengan berbagai teknik, menganalisis data, menarik kesimpulan dan mengkomunikasikan konsep, hukum atau prinsip yang ditemukan (Fadhilaturrahmi, 2017: 109-118). Sintesisnya adalah model pembelajaran saintifik merupakan pembelajaran dengan pendekatan yang berpusat kepada siswa agar secara aktif mendapatkan pengetahuan dengan prosedur yang didasarkan pada suatu metode ilmiah yaitu melalui tahapan - tahapan mengamati, merumuskan masalah, mengajukan atau merumuskan hipotesis, mengumpulkan data dengan berbagai teknik, menganalisis data, menarik kesimpulan dan mengkomunikasikan konsep, hukum atau prinsip yang ditemukan.

Konstruktivisme adalah suatu pendapat yang menyatakan bahwa perkembangan kognitif merupakan suatu proses pembelajar secara aktif membangun sistem arti dan pemahaman terhadap realita melalui pengamatan dan interaksi mereka. Menurut pandangan konstruktivisme pembelajar secara aktif membangun pengetahuan secara terus menerus mengasimilasi dan mengakomodasi informasi baru (Waseso, 2018:59-72). Fokus utama konstruktivisme adalah bahwa pengetahuan dikonseptualisasikan sebagai proses di mana pelajar secara aktif membangun makna dan belajar melalui pengalaman. Menurut paham konstruktivisme, pengetahuan tidak dapat ditransfer begitu saja dari seseorang kepada yang lain, tetapi harus diinterpretasikan sendiri oleh tiap - tiap orang. Manusia mengkonstruksi pengetahuan melalui interaksi dengan objek, fenomena, pengalaman dan lingkungan. Suatu pengetahuan dianggap benar bila pengetahuan itu dapat berguna untuk menghadapi dan memecahkan persoalan yang sesuai (Rangkuti, 2014:61-76). Dari pernyataan diatas maka dapat ditarik sintesis bahwa model pembelajaran konstruktivisme adalah pembelajaran dengan proses membangun atau menyusun pengetahuan baru dalam struktur kognitif siswa berdasakan pengalaman, pembelajar secara aktif membangun sistem arti dan pemahaman terhadap realita melalui pengamatan dan interaksi mereka, siswa belajar dengan mencocokan pengetahuan yang baru saja dipelajari dengan pengetahuan yang telah mereka ketahui. 
Kreativitas merupakan "kekayaan pribadi" (personal properties) yang diwujudkan dalam sikap atau karakter seperti fleksibel, terbuka, otonom, lapang dada, keinginan mencoba sesuatu (penasaran), firm (strong minded), kemampuan menjabarkan gagasan, kemampuan menilai diri sendiri secara realistis (mengenal dirinya: 'arafa nafsahu) yang kesemuanya diperlukan (prasyarat) untuk memunculkan kreaivitas (Pentury, 2017:265-272). Kreativitas dapat disimpulkan sebagai segala sesuatu berkaitan dengan cara atau upaya mengatasi berbagai masalah, mencari kualitas kehidupan pribadi, masyarakat dan organisasi. Kreativitas merupakan proses berpikir menemukan hal baru, hubungan baru, mengajukan dan menguji hipotesis, metoda atau cara unik dalam memecahkan masalah. (A'yuna, 2015: 1-19). Dari beberapa pendapat diatas, maka dapat ditarik sintesis bahwa kreativitas adalah kemampuan seseorang untuk menciptakan atau memadukan kombinasi antara ide dan imajinasi atau karya sebelumnya sehingga menghasilkan sesuatu yang baru dan orisinil yang dapat dimengerti sehingga dapat berguna dalam memecahkan masalah yang ada

\section{METODE PENELITIAN}

Metode penelitian yang digunakan dalam penelitian ini adalah penelitian kualitatif deskriptif. Penelitian kualitatif merupakan metode dengan beraneka segi fokus yang meliputi suatu interpretif, konstruktif, pendekatan naturalistik pada subjeknya. Hal ini bermakna penelitian kualitatif mempelajari sesuatu pada sudut pandang alamiahnya, menerjemahkannya, dan melihat fenomena dalam hal makna yang dipahami manusia. Penelitian ini dilakukan untuk mendeskriptifkan pandangan dan prespektif melalui kondisi dunia nyata dengan menggunakan banyak sumber sebagai bukti mengenai manajemen sekolah pada jenjang sekolah menengah pertama di Sekolah Anak Indonesia penerapan model pembelajaran APEL (Anak Pelaku Pembelajaran). Selanjutnya dilakukan kajian lebih mendalam mengenai sub fokus dari penelitian ini, yaitu tahapan manajemen mulai dari perencanaan, pengoranisasian, pengarahan/ penggerakan dan pengendalian dalam penerapan pembelajaran APEL (Anak Pelaku Pembelajaran) dalam rangka meningkatkan kreativitas siswa dari Papua.

\section{HASIL DAN PEMBAHASAN}

Pembelajaran APEL sebagai media dalam mencapai tujuan sekolah dapat dikatakan bahwa SMP SAI melakukan manajemen pembelajaran dengan mengelola kegiatan perencanaan, pengorganisasian, pengendalian (pengarahan) dan pengevaluasian kegiatan yang berkaitan dengan proses membelajarkan siswa dengan mengikut-sertakan berbagai faktor di dalamnya guna mencapai tujuan (Priyadi, 2017: 86-102).

Berikut penjabaran dimulai dari perencanaan, pengorganisasian, pengarahan dan penngendalian model pembelajaran APEL (Anak Pelaku Pembelajaran) di Sekolah Menengah Pertama Sekolah Anak Indonesia: Pada tahap perencanaan diperoleh bahwa model pembelajaran APELyang memiliki karakter mengacu pada kecakapan Abad 21 yaitu kemampuan 4C (Communication, Collaboration, Critical Thinking and Creativity), fokus pada kemampuan critical thinking dan creativity, yang mana siswa tidak hanya dibekali kemampuan secara akademis namun juga dibekali kemampuan untuk bertahan hidup. Siswa sebagai pelaku pembelajaran berperan aktif dalam proses pembelajaran di kelas, dibantu oleh guru yang berfungsi sebagai fasilitator melalui bertanya, mencari tahu, membuat hipotesa, menganalisis data dan membuat kesimpulan. Hal tersebut dapat dinyatakan bahwa SMP SAI mempersiapkan siswa melalui perencanaan yang mana proses tahapan awal penentuan tujuan organisasi (perusahaan) dan kemudian menyajikan (mengartikulasikan) dengan jelas strategi - strategi (program), taktik taktik (tata cara pelaksanaan program) dan operasi (tindakan) yang diperlukan untuk mencapai tujuan perusahaan secara menyeluruh (Harahap, 2017:211-234). Tahapan perencanaan pembelajaran APEL adalah dimulai dari pembahasan awal pada rapat kerja yang diketuai Kepala Sekolah dengan dibantu Tim Perumus APEL, yang selanjutnya melakukan pengarahan pada pelaksanaannya, tahap selanjutnya guru diberikan pelatihan oleh tim perumus untuk bekal persiapan mengajar di kelas dengan pembelajaran APEL kemudian guru membuat RPP kemudian diperiksa oleh tim perumus dan disetujui oleh Kepala Sekolah. Persiapan siswa dalam mengikuti pemeblajaran APEL tertuang pada peraturan akademik. Berdasarkan perencanaan yang telah ditetapkan pada manajemen model pembelajaran APEL (Anak Pelaku Pembelajaran), selanjutnya disusun pengorganisasian yang diawali dengan dibentuknya struktur organisasi. Struktur organisasi di Sekolah Menengah Pertama Sekolah Anak Indonesia yang tertinggi ada pada yayasan, kemudian diturunkan kepada Kepla Sekolah yang didampingi Wakil Kepala Sekolah pada bidang masing - masing dan ada guru serta tenaga kependidikan. Langkah tersebut sesuai dengan pernyataan Harahap (2017:211-234) bahwa pengorganisasian adalah proses kegiatan penyusunan anggota dalam bentuk struktur organisasi sesuai dengan tujuan - tujuan, sumber - sumber, dan lingkungannya. Bagian dari unsur pengorganisasian adalah "division of work" pembagian tugas, tentu tugas ini disesuaikan dengan bidangnya pada masing - masing. Hal tersebut didukung oleh Saefrudin (2017:56-67) yang menyatakan bahwa pengorganisasian adalah proses membagi kerja ke dalam tugas - tugas yang lebih kecil, membebankan tugas - tugas itu kepada orang yang sesuai dengan kemampuannya, dan mengalokasikan sumber daya, serta mengkoordinasikannya dalam rangka efektivitas pencapaian tujuan organisasi.

Sumber daya di Sekolah Menengah Pertama Sekolah Anka Indonesia pada dasarnya terdiri dari 3 yaitu sumber daya pembelajaran, sumber daya administratif dan sumber daya pengelolaan sekolah atau keuangan. Kriteria siswa yang bisa masuk ke Sekolah Menengah Pertama Sekolah Anak Indonesia adalah anak dari daerah tertinggal, khususnya Papua. Untuk kriteria 
guru di sekolah SAI kriterianya, antara lain: Komunikatif dan adaptif, Sehat secara fisik dan rohani, Menyukai dunia pendidikan dan dunia anak, Pendidikan minimal S1, Kreatif dan Inovatif, Bersedia menjalankan pembelajaran APEL di kelas

Berdasarkan pengorganisasian yang telah ditetapkan pada manajemen model pembelajaran APEL (Anak Pelaku Pembelajaran), maka disusun pengarahan dan penggerakan. Siriyei (2014: 244-251) berpendapat bahwaActuating atau fungsi penggerakan pelaksanaan adalah proses bimbingan kepada staf agar mereka menjalankan tugas - tugas pokoknya sesuai dengan keterampilan yang dimiliki (quality of care) dan dukungan sumber daya yang tersedia (quality of service). Kepala Sekolah dalam pembelajaran APEL menggerakkan bawahannya melalui menunjuk PJ (penanggung jawab) pembelajaran APEL kepada tim khusus perumus pembelajaran APEL, yang selanjutnya oleh tim perumus disosialisasikan kepada setiap guru mata pelajaran. Sampai pada guru, pelaksanaan pembelajaran APEL harus sesuai pedoman yang sudah dibentuk sebelumnya. Bagi semua guru akan dibekali dengan pelatihan mengenai model pembelajaran APEL. Maka alur pendelegasian wewenang dalam pengarahan dimulai dari Ketua Yayasan kemudian delegasi diteruskan kepada Kepala Sekolah dengan dibantu tim perumus APEL kemudia diteruskan kepada guru mata pelajaran.

Pelaksanan sepenuhnya yang tertuang di RPP, penyusunanya oleh guru dengan didampingi oleh tim perumus APEL. Guru mempersiapkan siswa dalam pembelajaran APEL dimulai dari menerima hasil assessment awal penerimaan murid baru, dari hasil tersebut maka guru wajib menyesuaikan persiapan dengan kemampuan siswa. Persiapan juga menyangkut bagaimana guru akan membantu menggali potensi yang ada pada siswa.

Berdasarkan pengarahan yang telah ditetapkan dan pelaksanaan pada manajemen model pembelajaran APEL (Anak Pelaku Pembelajaran), maka disusun pengendalian. Monitoring dan evaluasi ada 2 tipe, yaitu Kepala Sekolah kepada guru dan guru kepada siswa. Penerapan pengendalian di SMP Sekolah Anak Indonesia ini selaras dengan pernyataan Tantri (2017:1-8) yang menyatakan bahwa pengendalian manajemen sebagai proses yang manajemennya menjamin bahwa organisasi telah melaksanakan strateginya dengan efektif dan efisien. Dalam hal ini, efektivitas diukur berdasarkan kaitan antara keluaran pusat pertanggung jawaban dengan tujuan atau target yang ditetapkan, sedangkan efisiensi adalah perbandingan antara keluaran dengan masukan pusat pertanggung jawaban.

Bentuk instrumen monitoring dan evaluasi adalah dokumen evaluasi diri untuk guru. Instrumen guru menilai siswa untuk penilaian pembelajaran APEL melalui ujian semester baik UTS maupun UAS, guru dibantu tim permus APEL membuat soal - soal untuk siswa, soal biasanya memuat tentang apa yang dipelajari selama 1 semester melalui pembelajaran APEL. Jadi, penilaiannya apakah hasil pelaksanaannya tidak bertentangan dengan sasaran (goals) dan rencananya (plans). Bila terlihat adanya penyimpangan - penyimpangan perlu segera diadakan perbaikan (Ilham, 2014:37-50). Untuk faktor pendukungnya, ada dukungan besar dari yayasan untuk pengembangan model pembelajaran APEL ini. Faktor penghambatnya adalah kurangnya tenaga ahli pada tim perumus APEL, maka ini perlu selalu dilakukan kaderisasi kepada guru - guru yang sudah senior.

\section{SIMPULAN}

Keberhasilan manajemen pembelajaran APEL (Anak Pelaku Pembelajaran) di Sekolah Menengah Pertama Sekolah Anak Indonesia dalam upaya meningkatkan kreativitas siswa dari Papua tidak terlepas dari proses perencanaan, pengorganisasian, pengarahan, dan pengendalian yang tersusun dan terstruktur baik dan rapi. Berdasarkan analisis yang telah dilakukan terhadap data dan informasi mengenai proses manajemen di Sekolah Menengah Pertama Sekolah Anak Indonesia, maka dapat dijabarkan kesimpulan sebagai berikut:

a. Perencanaan

Kesimpulan yang diperoleh pada proses perencanaan model pembelajaran APEL, dibutuhkan adanya perencanaan yang khusus mengingat model pembelajaran ini adalah hasil pengembangan internal sekolah. Siswa sebagai pelaku pembelajaran berperan aktif dalam proses pembelajaran di kelas. Tujuannya adalah untuk merubah anak yang jauh dari modernisasi dan rasa percaya diri yang rendah menjadi anak yang kreatif dan inovatif, berwawasan internasinal dan memiliki karakter sebagai pemimpin untuk kemudian kembali ke daerahnya untuk ikut serta dalam membangun daerahnya dari ketertinggalan

Pada proses perencanaan, hal yang khusus dilakukan sekolah adalah dibentuknya tim perumus APEL yang menjadi penanggung jawab pelaksanaan di lapangan, dan sebelum guru melakukan kegiatan belajar mengajar wajib mengikuti pelatihan dan pembekalan APEL. Tim perumus APEL membantu guru mempersiapkan diri dalam kegiatan belajar mengajar, mulai dari pembekalan, pendampingan dalam pembuatan silabus dan RPP

b. Pengorganisasian

Pengorganisasian diawali dengan penyusunan struktur organisasi yang disusun menyesuaikan dengan kebutuhan. Pengorganisasian sekolah dalam penyelenggaraan program pendidikan didukung dengan sumber daya yang memadai. Sumber daya di Sekolah Menengah Pertama Sekolah Anak Indonesia pada dasarnya terdiri dari 3 yaitu sumber daya pembelajaran, sumber daya administratif dan sumber daya pengelolaan sekolah atau keuangan. Kriteria untuk guru di sekolah ini minimal S1 dengan jurusan mata pelajaran yang dikuasai dan bersedia menjalankan pembelajaran APEL selama mengajar di sekolah, kriteria siswa yang bisa masuk ke Sekolah Menengah Pertama Sekolah Anak Indonesia adalah anak dari daerah tertinggal, khususnya Papua. 
Pada pengorganisasian pembelajaran APEL dimulai dari mempersiapkan semua sumber daya yang diantaranya adalah sumber daya pembelajaran, sumber daya administratif dan sumber daya pengelolaan sekolah atau keuangan

c. Pengarahan dan pelaksanaan

Pengarahan dalam pengelolaan sekolah dilakukan melalui alur pendelegasian wewenang yang dimulai dari Yayasan sebagai pengayom sekaligus pengawas, didelegasikan kepada Kepala Sekolah dibantu oleh Wakli Kepala Sekolah diteruskan kepada Tim Perumus APEL sebagai penanggung jawab pelaksanaan APEL mulai dari persiapan sampai dengan evaluasi. Pelaksanan sepenuhnya yang tertuang di RPP, penyusunanya oleh guru dengan didampingi oleh tim perumus APEL utamanya dalam kaitannya dengan proses pembelajaran APEL di kelas. Pembelajaran diawali dengan scientific method melalui tahapan yaitu proses bertanya, mengamati, membuat hipotesis, uji hipotesis, analisis data, kesimpulan, dan presentasi kemudian mengarah kepada tahap akhir yaitu engineering design. Langkah engineering design berawal dari suatu masalah lalu siswa merancang solusi dan menerapkan solusi tersebut untuk menyelesaikan masalah kemudian mengevaluasi secara berulang, semua proses pelaksanaan didampingi guru yang berperan sebagai fasilitator.

d. Pengendalian

Monitoring dan evaluasi pembelajaran APEL ada 2 tipe, yaitu Kepala Sekolah kepada guru dan guru kepada siswa. Tim perumus APEL membantu Kepala Sekolah dalam monitoring dan evaluasi pembelajaran APEL oleh guru, ada dokumen penilaian yang dilakukan selama guru melaksanakan pembelajaran APEL. Tim perumus APEL juga membantu guru dalam melakukan monitoring dan evaluasi kepada siswa.

Bentuk instrumen monitoring dan evaluasi adalah dokumen evaluasi diri untuk guru. Instrumen guru menilai siswa untuk penilaian pembelajaran APEL melalui ujian semester baik UTS maupun UAS. Faktor pendukungnya, ada dukungan besar dari yayasan untuk pengembangan model pembelajaran APEL ini. Faktor penghambatnya adalah kurangnya tenaga ahli pada tim perumus APEL, maka ini perlu selalu dilakukan kaderisasi kepada guru- guru yang sudah senior..

\section{REFERENSI}

A’yuna, Q. (2015). Kontribusi Peran Orangtua Dan Guru Mata Pelajaran Terhadap Pengembangan Kreativitas Siswa. Jurnal Ilmiah Edukasi, 1(1), 1-19. https://doi.org/10.22373/je.vli1.314

Andiasari, L. (2015). Penggunaan Model Inquiry dengan Metode Eksperimen dalam Pembelajaran IPA di SMPN 10 Probolinggo. Jurnal Kebijakan Dan Pengembangan Pendidikan, 3(1), 15-20.

Fadhilaturrahmi. (2017). Penerapan Pendekatan Saintifik Untuk Meningkatkan Kemampuan Komunikasi Matematik Peserta Didik di Sekolah Dasar. EduHumaniora: Jurnal Pendidikan Dasar, 9(2), 109-118.

Kurdi, Fauziah Nuraini. (2009). Penerapan Student-Centered Learning Dari Teacher-Centered Learning Mata Ajar Ilmu Kesehatan Pada Program Studi Penjaskes. Jurnal Forum Kependidikan, 28(2), 108-113.

Harahap, S. (2017). Implementasi Manajemen Syariah Dalam Fungsi-Fungsi Manajemen. Journal At-Tawassuth, 2(1), 211-234.

Ilham. (2014). Penerapan Fungsi-Fungsi Manajemen dalam Bimbingan dan Konseling Agama Islam. Alhadharah : Jurnal Ilmu Dakwah, 13(25), 37-50.

Millah, D. (2015). Audience Centered pada Metode Presentasi Sebagai Aktualisasi Pendekatan Student Centered Learning. Jurnal Penelitian Pendidikan Islam : Edukasia, 10(2), 255-278.

Mubarok, C., \& Sulistyo, E. (2014). Penerapan Model Pembelajaran Discovery Learning Terhadap Hasil Belajar Siswa Kelas X TAV Pada Standar Kompetensi Melakukan Instalasi Sound System di SMK Negeri 2 Surabaya. Jurnal Pendidikan Teknik Elektro, 3(1), 215-221.

Muhlasin. (2019). Manajemen Pembelajaran Dalam Rangka Meningkatkan Prestasi Belajar. Jurnal Akademika, 15(1), 62-75. https://doi.org/.1037//0033-2909.I26.1.78

Nafiah, Y. N., \& Suyanto, W. (2014). Penerapan Model Problem Based Learning Untuk Meningkatkan Keterampilan Berpikir Kritis dan Hasil Belajar Siswa. Jurnal Pendidikan Vokasi, Vol. 4(No 1), 125-143.

Pentury, H. J. (2017). Pengembangan Kreativitas Guru dalam Pembelajaran Kreatif Pelajaran Bahasa Inggris. Jurnal Lmiah Kependidikan, 4(3), 265-272.

Prasetyo, D. A., \& Widjanarko, D. (2015). Penerapan Model Pembelajaran Inkuiri Meningkatkan Hasil Belajar SIswa Pada Kompetensi Memelihara Komponen Sistem Bahan Bakar Bensin. Jurnal Pendidikan Teknik Mesin, 15(2), 82-86.

Priyadi, R. (2017). Manajemen Pembelajaran International Baccalaureate Primary Years Program In Surabaya Intercultural School. Jurnal Manajerial Bisnis, 1(1), 86-102.

Rangkuti, A. N. (2014). Konstruktivisme Dan Pembelajaran Matematika. Jurnal Darul 'Ilmi, 02(02), 61-76.

Rerung, N., Sinon, I. L. S., \& Widyaningsih, S. W. (2017). Penerapan Model Pembelajaran Problem Based Learning (PBL) Untuk Meningkatkan Hasil Belajar Peserta Didik SMA Pada Materi Usaha dan Energi. Jurnal Ilmiah Pendidikan Fisika, 06(1), 4755. https://doi.org/10.24042/jpifalbiruni.v6i1.597 
Saefrudin. (2017). Pengorganisasian Dalam Manajemen. Jurnal Al-Hikmah, 5(2), 56-67. https://doi.org/10.1017/CBO9781107415324.004

Salmi. (2019). Penerapan Model Pembelajaran DIscovery Learning Dalam Meningkatkan HAsil Belajar Ekonomi Peserta Didik Kelas XII IPS 2 SMA Negeri 13 Palembang. JURNAL PROFIT, 6(1), 1-16.

Setiawan, D. (2017). Pendekatan Saintifik dan Penilaian Autentik Untuk Meningkatkan Mutu Pembelajaran Penmdidikan Agama Islam. Al-ASASIYYA: Journal Of Basic Education, 01(02), 34-46.

Siriyei, I., \& Wulandari, R. D. (2013). Faktor Determinan Rendahnya Pencapaian Cakupan Standar Pelayanan Minimal Bidang Kesehatan di Puskesmas Mojo Kota Surabaya. Jurnal Administrasi Kesehatan Indonesia, 1(3), 244-251. https://ejournal.unair.ac.id/JAKI/article/view/6895/6410

Sufairoh. (2016). Pendekatan Saintifik \& Model Pembelajaran K-13. JURNAL PENDIDIKAN PROFESIONAL, 5(3), 116-125.

Sulaeman, T., \& Hamdani, M. D. Al. (2017). Manajemen Pembelajaran Modern di Madrasah Diniyah Takmiliyah An Nuur Sindangkasih Kabupaten Ciamis. Jurnal Tsamrah Al Fikri, 11, 99-132.

Tantri, E., Sumarsan, T., \& Rumapea, M. (2017). Analisis Management Controlling System Terhadap Fungsi Perencanaan, Pengawasan dan Implementasi Tujuan Pada PT Citra Robin Sarana. Jurnal Majalah Ilmiah Methoda, 7(1), 1-8.

Waseso, H. P. (2018). Kurikulum 2013 Dalam Prespektif Teori Pembelajaran Konstruktivis. TA'LIM : Jurnal Studi Pendidikan Islam, 1(1), 59-72. Yogyakarta: Pustaka Pelajar 